\title{
Seasonal variation in the chemical composition and carbohydrate signature compounds of biofilm
}

\author{
Fraddry D'Souza, Anita Garg, Narayan B. Bhosle* \\ Marine Corrosion and Material Research Division, National Institute of Oceanography, Dona Paula 403 004, Goa, India
}

\begin{abstract}
Biofilm developed on stainless steel was characterised using biological, chemical and biochemical parameters, as well as aldose molecular biomarkers. Biofilm biomass and carbohydrate concentration increased on stainless steel, whereas C:N and organic carbon:chlorophyll a ratios decreased over the period of immersion. Despite the abundance of microalgal biomass, carbohydrate concentration was lower than that observed for proteins. Carbohydrate composition varied during the period of immersion. Glucose, arabinose and xylose were relatively more abundant during the initial period ( $5 \mathrm{~d}$ ) of immersion, whereas rhamnose, fucose, ribose and galactose were more abundant during the latter period ( $>5 \mathrm{~d}$ ) of immersion. The sugar distribution trends suggest that biofilm carbohydrates were mostly derived from degraded biogenic and/or terrestrial sources, especially during the initial period ( $<5 \mathrm{~d})$ of immersion. As the period of immersion increased, the contribution of biogenic sources to the biofilm carbohydrates increased. This conclusion was also supported by principal component analysis based on wt \% aldose composition. Multi-parameter approaches such as the one used in the present study provide a better picture of the sources and nature of biofilm organic matter.
\end{abstract}

KEY WORDS: Biofilm biomass $\cdot$ Carbohydrates $\cdot$ Aldose $\cdot$ Organic matter $\cdot$ Stainless steel

\section{INTRODUCTION}

Surfaces immersed in an aquatic environment rapidly adsorb dissolved organic matter, thereby conditioning the surface (Loeb \& Neiholf 1977, Characklis \& Escher 1988, Taylor et al. 1997, Compere et al. 2001). Conditioned surfaces are then colonised by microorganisms. Such attachment and growth of microorganisms on surfaces is generally defined as biofilm (Characklis \& Cooksey 1983, Decho 2000). While attaching to surfaces, microorganisms produce extracellular polymeric substances (EPS), generally rich in carbohydrate polymers (Decho 1990, Welch et al. 1999, Wingender et al. 1999). These carbohydrate polymers play an important role in the maintenance and protection of biofilm (Costerton et al. 1987, Read \& Costerton 1987, Wolfaardt et al. 1999).

Carbohydrates of organisms have been classified as storage and structural polysaccharides. Storage polysaccharides (labile sugars) are rapidly utilised by in situ organisms (Handa \& Tominaga 1969, Ittekkot et al.
1982, Tanoue \& Handa 1987, D'Souza \& Bhosle 2001). Such selective utilisation of storage polysaccharides results in the accumulation of relatively less degradable structural polysaccharides (refractory sugars) (Cowie \& Hedges 1992, Burdige et al. 2000, Ogier et al. 2001). Structural polysaccharides are relatively more refractory in nature, and so they are likely to leave a signature of the original source material in the sample. Therefore, aldoses, the monomeric units of carbohydrates, are often used as useful tools to distinguish inputs from terrestrial and marine sources in aquatic environments (Cowie \& Hedges 1984).

Most previous studies on biofilm have focused on the microscopic biological characterisation and/or the analysis of the bulk chemical compounds, such as organic carbon and nitrogen (Baier 1984, Bhosle et al. 1989, Maki et al. 1990, Bott 1993, Sonak \& Bhosle 1995, D'Souza \& Bhosle 2003a). Conversely, little is known, on a molecular level, concerning the biochemical characteristics of biofilms that develop on surfaces immersed in seawater (White \& Benson 1984, 
Khandekar \& Johns 1990, Bhosle \& Wagh 1997, D'Souza \& Bhosle 2003b). Such studies on detailed molecular composition, nature and short-term temporal variation would help in understanding the dynamics, origin and nutritional value of the biofilm organic matter (OM) (Hedges et al. 1994). Moreover, increased knowledge of the chemical composition on a molecular level and the kinetics of the biofilm OM is central to a sound scientific understanding of biofilm growth and adhesion mechanisms, as well as to assessments of the effect of specific organic molecules on the settlement of invertebrate larvae (Wieczorek et al. 1995).

The aims of the present study were: (1) to assess the seasonal variations in biofilm carbohydrates over the initial $15 \mathrm{~d}$ immersion period, (2) to identify the sources of biofilm carbohydrates and (3) to assess the nature of the biofilm OM over the period of immersion.

\section{MATERIALS AND METHODS}

Test panels and deployment. Twenty stainless steel (SS) panels $(25 \times 20 \times 0.05 \mathrm{~cm})$ were cleaned, sterilised and deployed in the surface waters $(\sim 2 \mathrm{~m})$ of Dona Paula Bay $\left(15.31^{\circ} \mathrm{N}, 73.59^{\circ} \mathrm{E}\right)$ following procedures described earlier (Sonak \& Bhosle 1995, Bhosle \& Wagh 1997, D'Souza \& Bhosle 2003b). Panels were deployed in April/May 1999, April/May 2000, September 2000 and January 2001. The panels (4) were retrieved on Days 1, 3, 5, 10 and 15 following immersion.

Collection of samples. After retrieval, biofilm material from the test panels was removed using a nylon brush and filter-sterilised seawater $\left(0.2 \mu m_{i}\right.$ Nuclepore) (Sharma et al. 1990, Sonak \& Bhosle 1995, Bhosle \& Wagh 1997, D'Souza \& Bhosle 2003b). The scraped biofilm material was collected to a known volume. A known aliquot was filtered through pre-ignited $\left(450^{\circ} \mathrm{C}, 3 \mathrm{~h}\right) \mathrm{GF} / \mathrm{F}$ filters $(47 \mathrm{~mm}, 0.7 \mu \mathrm{m}$ pore size) for the analysis of organic carbon (OC), organic nitrogen $(\mathrm{ON})$, chlorophyll $a(\mathrm{chl} a)$, proteins, total carbohydrate $\left(\mathrm{TCHO}_{\mathrm{SP}}\right)$ and aldoses. For bacterial counts, 0.5 to $1 \mathrm{ml}$ of the scraped material was fixed with filter-sterilised ( $0.2 \mu \mathrm{m}$ filter) $2 \%$ formaldehyde and then stored in a refrigerator at $4^{\circ} \mathrm{C}$ until analysis. Chl a samples were processed immediately, whereas the filters employed for all other parameters were stored at $-20^{\circ} \mathrm{C}$ until analysis. All the samples were analysed in triplicate.

Analysis of samples. Chl a was analysed by spectrophotometry (Parsons et al. 1984). The OC was estimated following the method of Parsons et al. (1984). The ON was quantified using the method of Smart et al. (1983). Proteins were analysed by the bicinchonic acid method (Smith et al. 1985). TCHO $\mathrm{SP}_{\mathrm{SP}}$ wanalysed using the phenol-sulphuric acid method (Dubois et al.
1956). The precision of the analytical methods based on 3 replicates was better than $6 \%$.

To estimate total bacterial counts (TBC) a known volume $(0.2 \mathrm{ml})$ of the sample was stained with $0.1 \%$ acridine orange and filtered through $0.2 \mu \mathrm{m}$ Nucleopore filters. Bacteria were counted in 10 randomly selected fields using an epifluorescence microscope (Olympus CX40), as suggested by Parsons et al. (1984).

Aldose composition of the biofilm and the probable sources such as fouling bacteria, diatoms (Navicula sp. and Amphora sp.), macroalgae (Gracilaria sp. and Sphacelaria furcigera) and mangrove leaves (Kandelia sp. and Rhizophora sp.) were determined using the capillary gas chromatographic (GC) technique (Bhosle et al. 1995, D'Souza et al. 2003). In the present study, total aldoses have been defined as the sum of all identified aldoses. The contribution of an individual aldose to the total aldoses is expressed as a percentage of the total weight (wt \%). Analytical reproducibility of the GC method was greater than $\pm 6 \%$, whereas it was higher than $\pm 10 \%$ for the GC plus sample preparation method.

Statistical analysis. A simple regression analysis was employed to assess the relationship between various parameters using the Excel program on a personal computer (Sokal \& Rohlf 1981). A 2-way analysis of variance (ANOVA) was carried out to determine if there were significant daily and seasonal variations in biofilm development. Principal component analysis (PCA) based on wt \% aldose composition was performed following the procedure described earlier (D'Souza \& Bhosle 2001, D'Souza et al. 2003).

\section{RESULTS}

\section{Biomass, chemical and biochemical composition}

The biofilm biomass on SS (measured as OC, ON, proteins, chl $a$ and TBC) showed small changes over the first $5 \mathrm{~d}$ period of immersion (Fig. 1). Thereafter, the biofilm biomass increased over the subsequent period of immersion: values were higher in September 2000 (monsoon) compared to those recorded in January 2001 (post-monsoon), whereas intermediate values were recorded for both the pre-monsoon seasons (April/May 1999 and 2000) (Fig. 1). The 2-way ANOVA of the biomass parameters showed significant daily variations $(F=8.48$ to $171.20 ; \mathrm{p}>0.001)$; however, the seasonal variations were not significant ( $F=0.75$ to 17.88 ; p > 0.01 to 0.50$)$, except for TBC $(F=17.88$; $\mathrm{p}>0.001)$. Highly significant positive correlations were observed between various biomass parameters (Table 1). Furthermore, carbohydrates and proteins showed significant positive relationships with both 

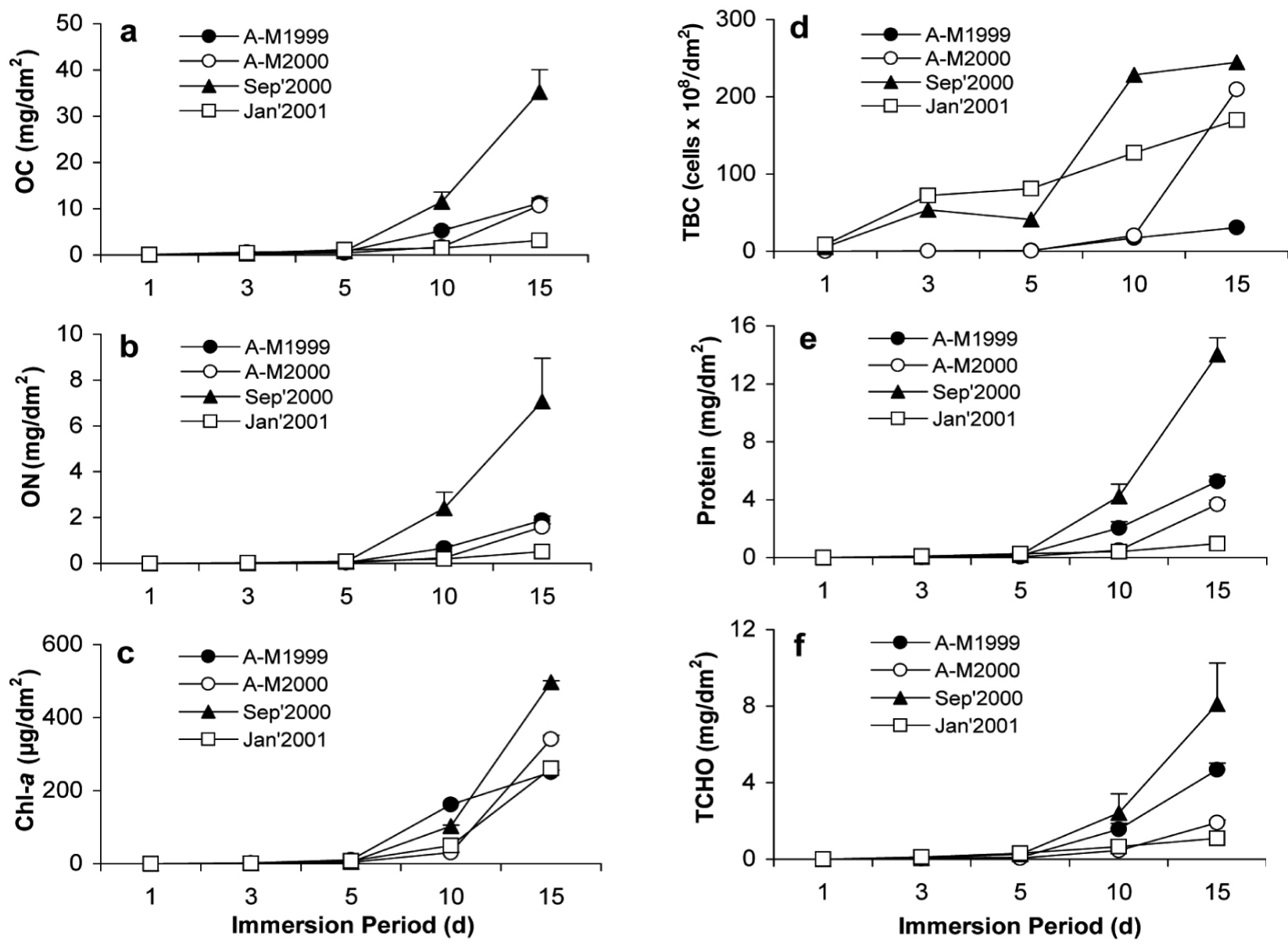

Fig. 1. Changes in (a) biofilm organic carbon (OC), (b) organic nitrogen (ON), (c) chlorophyll a (chl a), (d) total bacterial counts (TBC), (e) protein and (f) total carbohydrates (TCHO) on stainless steel panels immersed in the surface seawaters of Dona Paula Bay over a period of 15 d in April/May (A-M) 1999, April/May 2000, September 2000 and January 2001. Error bars indicate mean \pm SD

chl $a$ and TBC. Both the C:N (atomic) and OC:chl $a$ (wt:wt) ratios were high at Day 1, then subsequently decreased over the period of immersion (Fig. 2). Concentrations of $\mathrm{TCHO}_{\mathrm{SP}}$ (Fig. 1f), contribution of $\mathrm{TCHO}_{\mathrm{SP}}-\mathrm{C}$ and protein-C to the total OC (Table 2) and the average protein: $\mathrm{TCHO}_{\mathrm{SP}}$ ratio (Fig. 2) of the biofilm generally increased over the period of immersion.
The wt \% contribution of glucose, arabinose and xylose to the total aldoses of the biofilm was high from Days 1 to 5 following immersion. Subsequently, as the period of immersion increased, the contribution of these sugars to the total aldoses decreased, while that of galactose, rhamnose, fucose and ribose generally increased (Fig. 3b).

\section{Aldose concentration and composition}

The concentrations of the total aldoses increased over the period of immersion (Fig. 3a). Total aldoses-C accounted for $\sim 10$ to 92 and 0.37 to $8.85 \%$ of $\mathrm{TCHO}_{\mathrm{SP}}-\mathrm{C}$ and $\mathrm{OC}$, respectively (Table 2). The relative distribution (as wt \%) of each aldose, however, varied over the period of immersion (Fig. 3b).
Table 1. Correlation coefficient $\left(r_{i} n=20\right)$ between various parameters of the biofilm on the stainless steel panels immersed in the surface waters of Dona Paula Bay over a period of $15 \mathrm{~d}$. OC: organic carbon; ON: organic nitrogen; TCHO: total carbohydrates; TBC: total bacterial counts. ${ }^{* * *} \mathrm{p}<0.001$

\begin{tabular}{|lllllll|}
\hline Parameter & OC & ON & Chl $a$ & TCHO & Protein & TBC \\
\hline OC & \multirow{2}{*}{1.000} & $0.996^{* * *}$ & $0.877^{* * *}$ & $0.969^{* * *}$ & $0.997^{* * *}$ & $0.917^{* * *}$ \\
ON & & 1.000 & $0.841^{* * *}$ & $0.957^{* * *}$ & $0.992^{* * *}$ & $0.933^{* * *}$ \\
Chl $a$ & & & 1.000 & $0.877^{* * *}$ & $0.871^{* * *}$ & $0.733^{* * *}$ \\
TCHO & & & & 1.000 & $0.982^{* * *}$ & $0.842^{* * *}$ \\
Protein & & & & & 1.000 & $0.906^{* * *}$ \\
TBC & & & & & & 1.000 \\
\hline
\end{tabular}


Table 2. Percent variation in the contribution of aldoses- $\mathrm{C}, \mathrm{TCHO}_{\mathrm{SP}}-\mathrm{C}$ and protein- $\mathrm{C}$ to organic carbon of the biofilm. $\mathrm{TCHO}_{\mathrm{SP}}$ : total carbohydrates by spectrophotometery

\begin{tabular}{|c|c|c|c|c|c|}
\hline Date & Aldoses-C:OC & $\mathrm{TCHO}_{\mathrm{SP}}-\mathrm{C}: \mathrm{OC}$ & Protein-C:OC & $\mathrm{TCHO}_{\mathrm{SP}}-\mathrm{C}+$ Protein-C & Aldoses-C: $\mathrm{TCHO}_{\mathrm{SP}}-\mathrm{C}$ \\
\hline \multicolumn{6}{|c|}{ April/May 1999} \\
\hline Day 1 & 0.68 & $2.77 \pm 0.40$ & $2.82 \pm 0.45$ & $5.59 \pm 0.23$ & 22.96 \\
\hline Day 3 & 0.45 & $4.15 \pm 1.14$ & $4.04 \pm 1.36$ & $8.19 \pm 2.33$ & 10.89 \\
\hline Day 5 & 1.04 & $4.36 \pm 0.48$ & $8.53 \pm 0.27$ & $12.89 \pm 0.74$ & 24.55 \\
\hline Day 10 & 4.06 & $12.43 \pm 1.37$ & $18.31 \pm 1.02$ & $30.74 \pm 0.51$ & 33.98 \\
\hline Day 15 & 3.03 & $16.71 \pm 1.28$ & $22.17 \pm 2.42$ & $38.88 \pm 3.60$ & 18.12 \\
\hline \multicolumn{6}{|c|}{ April/May 2000} \\
\hline Day 1 & 1.23 & $4.01 \pm 0.86$ & $1.93 \pm 0.89$ & $6.13 \pm 2.00$ & 29.35 \\
\hline Day 3 & 0.71 & $2.31 \pm 0.61$ & $4.10 \pm 0.85$ & $6.40 \pm 1.09$ & 28.14 \\
\hline Day 5 & 1.96 & $5.13 \pm 1.25$ & $5.82 \pm 0.71$ & $10.95 \pm 1.89$ & 38.17 \\
\hline Day 10 & 3.49 & $10.23 \pm 0.23$ & $13.42 \pm 0.23$ & $23.65 \pm 0.07$ & 33.39 \\
\hline Day 15 & 3.01 & $7.20 \pm 0.35$ & $16.21 \pm 1.26$ & $23.41 \pm 1.50$ & 42.09 \\
\hline \multicolumn{6}{|c|}{ September 2000} \\
\hline Day 1 & 2.19 & $3.78 \pm 1.22$ & $5.19 \pm 4.45$ & $8.97 \pm 5.67$ & 57.78 \\
\hline Day 3 & 3.63 & $6.58 \pm 0.90$ & $7.22 \pm 0.93$ & $13.81 \pm 1.55$ & 57.39 \\
\hline Day 5 & 8.85 & $12.00 \pm 1.14$ & $10.02 \pm 1.13$ & $22.02 \pm 2.22$ & 71.19 \\
\hline Day 10 & 6.31 & $8.55 \pm 0.65$ & $17.23 \pm 0.58$ & $25.78 \pm 1.23$ & 74.99 \\
\hline Day 15 & 8.61 & $10.33 \pm 3.89$ & $18.79 \pm 1.50$ & $29.12 \pm 5.39$ & 92.36 \\
\hline \multicolumn{6}{|c|}{ January 2001} \\
\hline Day 1 & 0.37 & $3.27 \pm 1.19$ & $2.53 \pm 2.17$ & $5.80 \pm 3.36$ & 11.46 \\
\hline Day 3 & 1.76 & $10.20 \pm 5.40$ & $9.69 \pm 2.20$ & $19.89 \pm 7.60$ & 17.86 \\
\hline Day 5 & 1.40 & $11.41 \pm 2.47$ & $11.39 \pm 4.02$ & $22.80 \pm 6.48$ & 12.13 \\
\hline Day 10 & 2.65 & $17.67 \pm 2.83$ & $12.80 \pm 2.62$ & $30.46 \pm 5.46$ & 14.97 \\
\hline Day 15 & 1.98 & $13.91 \pm 2.25$ & $14.31 \pm 1.09$ & $28.22 \pm 3.34$ & 14.26 \\
\hline
\end{tabular}

Biofilm sources such as bacteria and diatoms were relatively enriched in ribose, fucose and galactose (Table 3). Mangrove leaves showed an abundance of glucose, arabinose and xylose; glucose and mannose were more abundant in macroalgae.

PCA produced 2 factors: Factor 1 accounted for 62.2 to $74.1 \%$ of the variance, while Factor 2 gave 11.6 to $19.7 \%$ of the variance. The cumulative variance ranged between 80.6 and $85.7 \%$. The plots of PCA

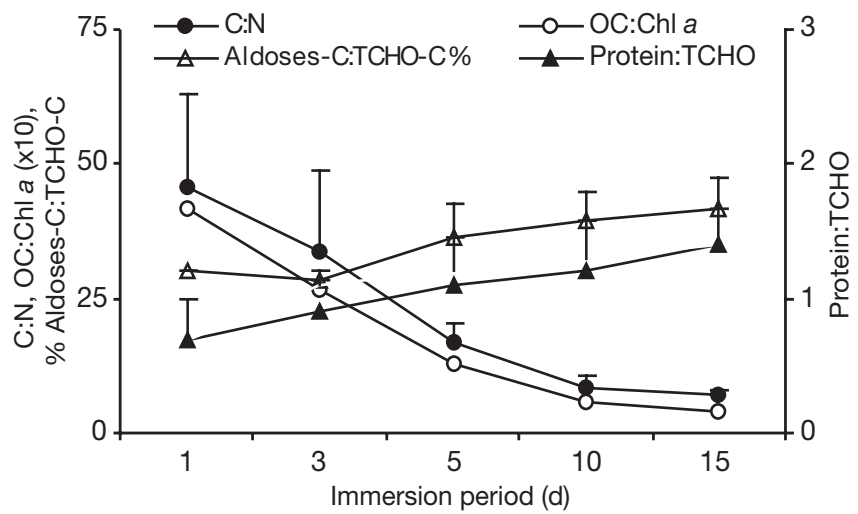

Fig. 2. Average changes in (4 observations) $\mathrm{C}: \mathrm{N}, \mathrm{OC}: \mathrm{chl} a$ $(\times 10)$, Protein: $\mathrm{TCHO}_{\mathrm{SP}}$ and \% Aldoses-C:TCHO-C ratios in the biofilm on stainless steel panels. Error bars indicate mean \pm SD
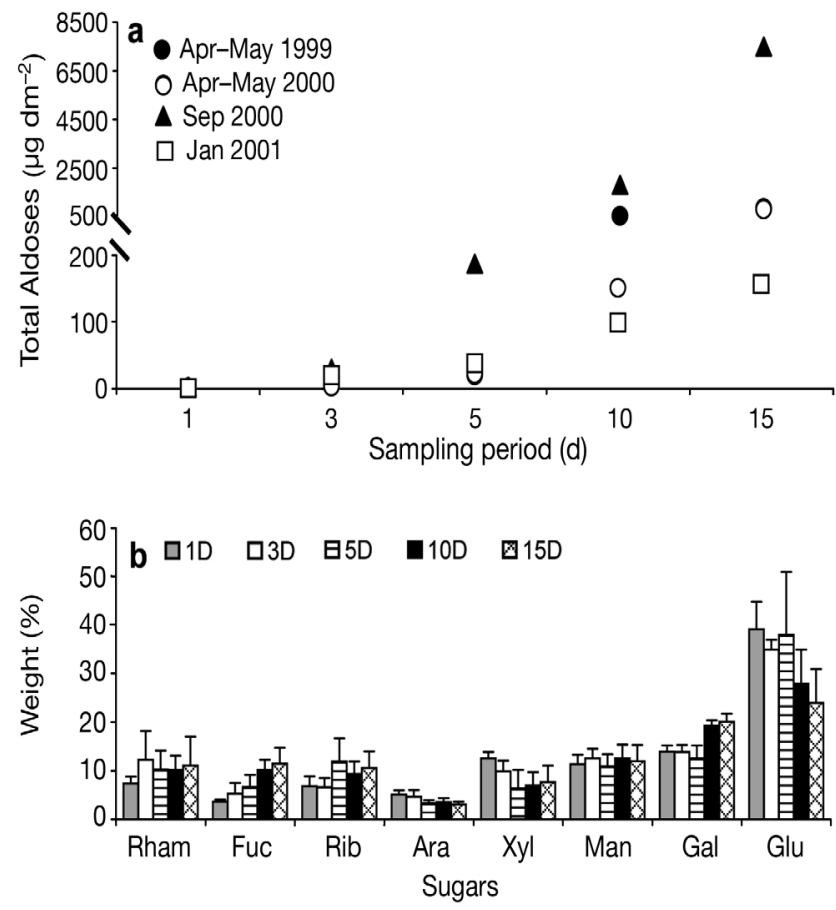

Fig. 3. Changes in average (a) total aldoses and (b) monosaccharide composition of the biofilm developed on stainless steel panels over a $15 \mathrm{~d}$ period of immersion in Dona Paula Bay, for all 4 sampling periods. Bars indicate mean $\pm \mathrm{SD}$. Rham: rhamnose; Fuc: fucose; Rib: ribose; Ara: arabinose; Xyl: xylose; Man: mannose; Gal: galactose; Glu: glucose 
loading factors 1 vs. 2 for the biofilm samples clearly separate the variables into clusters, and thus provide better insight into the relationships that exist among the variables (Fig. 4).

\section{DISCUSSION}

\section{Biofilm biomass}

Our main aim was to characterise carbohydrates during the initial stages of biofilm formation. Therefore, the biofilm development was assessed over a $15 \mathrm{~d}$ period of immersion. Normally, long-term immersion periods extending from months to years are generally employed to evaluate macrofouling. Similarly, the removal of biofilm is perhaps the most important step in evaluating biomass on a solid surface immersed in an aqueous environment. Removal of biofilm by brushing is one of the commonly employed techniques (White \& Benson 1984, Bhosle et al. 1989, Khandekar \& Johns 1990). Studies carried out in our laboratory suggest that scraping using a nylon brush removes $\sim 89 \pm$ $2 \%$ of the biofilm developed on metal and non-metal surfaces (Sharma et al. 1990). In our laboratory, a nylon brush was routinely used to remove biofilm from metal and non-metal surfaces (Bhosle et al. 1989, 1993, Bhosle \& Wagh 1997, D'Souza \& Bhosle 2001, 2003a, b, D'Souza 2004).

Biofilm biomass on SS generally increased over the period of immersion. The ANOVA analysis, however, indicated that the daily $(p>0.001)$ but not the seasonal ( $p>0.01$ to 0.5 ) variation in biofilm biomass was significant. In contrast, the physical, chemical and biological parameters of the surface seawater did not vary much during any of the sampling periods (D'Souza 2004). The observed increase in biofilm biomass was, therefore, due to an increase in settlement and/or growth of the attached microorganisms. The latter seems likely because the abundance of bacteria (TBC) and microalgae (chl a) in the biofilm on SS panels generally increased several-fold over the period of immersion (Fig. 1). This was also supported by the decreasing trends observed for the OC:ON and OC:chl a ratios of the biofilm (Fig. 2) (Verity et al. 1992, Oleson \& Lundsgaard 1995, Otero et al. 1998, Maksymowska et al. 2000, Verity 2002). Moreover, TBC and chl a showed significant relationships with the $\mathrm{OC}$ and $\mathrm{ON}$ of the biofilm, implying that bacteria and microalgae were important sources for these compounds (Table 1).

\section{Carbohydrate and protein concentrations}

Concentrations of both $\mathrm{TCHO}_{\mathrm{SP}}$ and protein increased over the period of immersion, indicating the production of these compounds by biofilm microorganisms. This was also evident from the significant positive relationships of these compounds with TBC and chl a. However, the concentrations of $\mathrm{TCHO}_{\mathrm{SP}}$ were relatively more abundant in biofilm during the first $5 \mathrm{~d}$ period of immersion. This was probably due to the presence of degraded OM, which is generally rich in $\mathrm{TCHO}_{\mathrm{SP}}$ compared to the protein. Alternatively, the higher amounts of $\mathrm{TCHO}_{\mathrm{SP}}$ in biofilm during the first $5 \mathrm{~d}$ following immersion may be due to induced production of these compounds by the attached microorganisms (Vandevivere \& Kirchman 1993).

Microorganisms, especially planktonic diatoms as well as laboratory-grown diatom biofilms, are known to produce large amounts of carbohydrates, particularly during the stationary growth phase and/or under nutrient stress conditions (Myklestad 1977, Bhosle et al. 1993). A number of diatoms including Navicula, Nitzschia, Pleurosigm, Licmophora and Amphora, etc. were present in the biofilm (D'Souza 2004). Despite the presence of these diatoms carbohydrate production was lower, as is evident from the increasing trends recorded for the protein:carbohydrate ratio of the biofilm over the period of immersion. The relative distribution of carbohydrates and proteins in microorganisms is influenced by their phase of growth. Labora-

Table 3. Monosaccharide composition (wt \%) of different biological sources. Sp. fr.: Sphacelaria furicigera

\begin{tabular}{|c|c|c|c|c|c|c|c|c|}
\hline \multirow[t]{2}{*}{ Sugar } & \multicolumn{2}{|c|}{- Bacteria -} & \multicolumn{2}{|c|}{$\longrightarrow$ Diatom -} & \multicolumn{2}{|c|}{ Mangrove } & \multicolumn{2}{|c|}{ — Macroalgae- } \\
\hline & Bacteria-1 & Bacteria-2 & Amphora & Navicula & Kandelia & Rhizophora & Gracilaria & Sp. fr. \\
\hline Rhamnose & 7.85 & 3.34 & 3.39 & 4.55 & 6.10 & 4.43 & 1.35 & 1.40 \\
\hline Fucose & 0.00 & 0.00 & 11.97 & 4.27 & 0.00 & 0.00 & 0.00 & 0.00 \\
\hline Ribose & 10.27 & 31.13 & 5.45 & 9.83 & 0.00 & 0.00 & 0.00 & 0.00 \\
\hline Arabinose & 3.87 & 1.50 & 0.86 & 0.27 & 14.14 & 9.78 & 3.60 & 2.05 \\
\hline Xylose & 7.77 & 1.66 & 14.67 & 11.76 & 16.27 & 9.27 & 4.97 & 4.90 \\
\hline Mannose & 29.41 & 15.66 & 4.37 & 10.55 & 4.50 & 25.56 & 6.17 & 12.05 \\
\hline Galactose & 24.49 & 40.95 & 24.59 & 35.02 & 6.71 & 9.73 & 34.69 & 21.17 \\
\hline Glucose & 16.34 & 5.76 & 34.69 & 23.75 & 52.28 & 41.22 & 49.21 & 58.43 \\
\hline
\end{tabular}



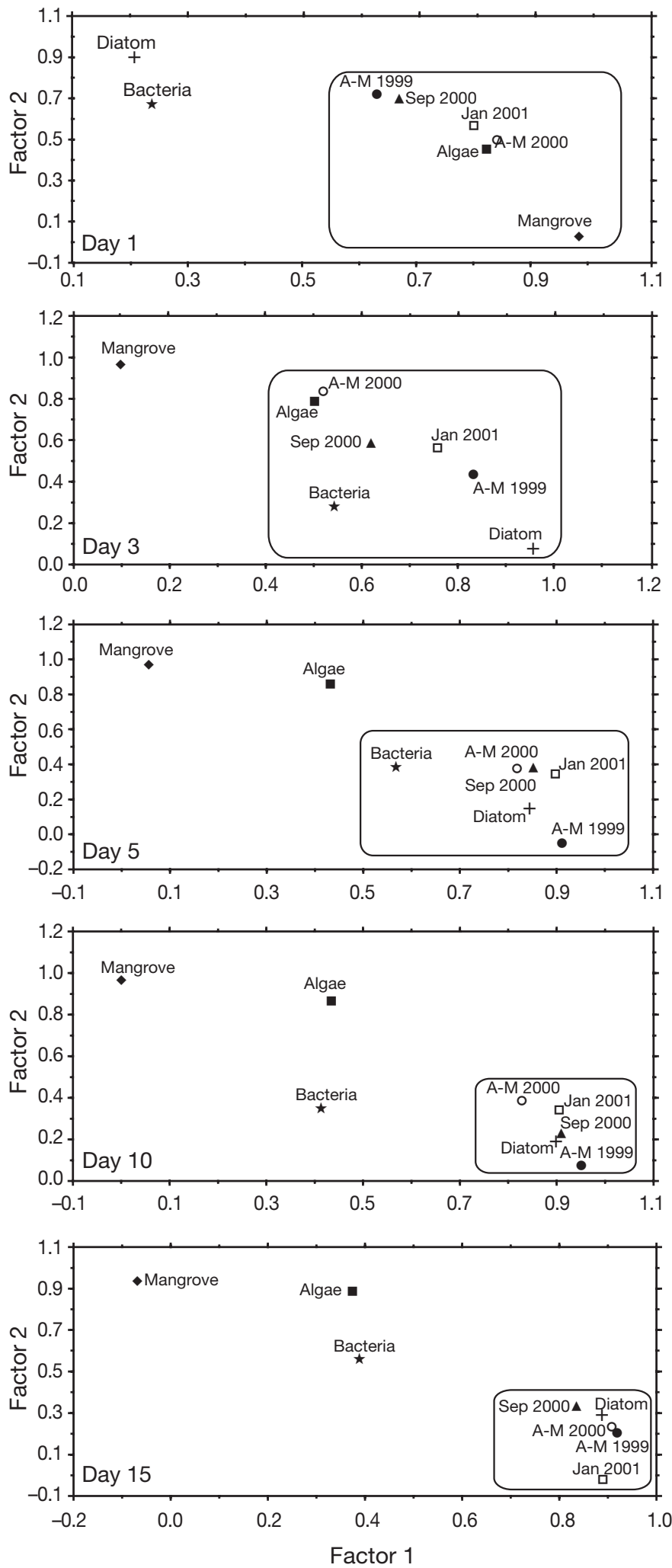

Fig. 4. Plot of loading factors of principal component analysis for the monosaccharide components of the biofilm material developed on stainless steel panels immersed in surface waters of the Dona Paula Bay over a period of $15 \mathrm{~d}$ in April/May 1999, April/May 2000, September 2000 and January 2001 tory-grown diatom cultures, bacteria and natural phytoplankton populations are known to produce lower amounts of carbohydrates and higher amounts of proteins during the early logarithmic growth phase (Myklestad 1977, Hitchcock 1978, Rice et al. 2000). Therefore, the observed differences in the relative distribution of $\mathrm{TCHO}_{\mathrm{SP}}$ and proteins in the biofilm may reflect the effect of the growth phase of the biofilm microorganisms.

Nutrients, especially the levels of nitrate and phosphate in the growth medium, are known to influence the relative distribution of carbohydrates and proteins in laboratory-grown bacteria and microalgae, as well as in natural populations of microorganisms (Corzo et al. 2000). Nitrate and phosphate concentrations in the biofilm were generally low at Day 1 of the immersion period (Rao 2003). Moreover, concentrations of both nitrate and phosphate in the surface seawaters of the study area varied over the period of sampling (D'Souza 2004). Therefore, the observed differences in the levels of $\mathrm{TCHO}_{\mathrm{SP}}$ and proteins in the biofilm may be related to the nutrient status of biofilm organisms and/or to the nutrient concentrations in surrounding seawaters.

\section{Aldose composition}

Neutral sugars were released from their original polymers by hydrolysis. Hydrolysis using $\mathrm{HCl}$ or $\mathrm{H}_{2} \mathrm{SO}_{4}$ is used for the analysis of neutral sugars in natural samples. Both the acids were tested for their ability to release the neutral sugars from biofilm samples (D'Souza 2004). Sugar yields were relatively high when the biofilm samples were subjected to strong hydrolysis using $72 \% \mathrm{H}_{2} \mathrm{SO}_{4}$ at room temperature for $2 \mathrm{~h}$, followed by mild hydrolysis using $1.2 \mathrm{M} \mathrm{H}_{2} \mathrm{SO}_{4}$ at $100^{\circ} \mathrm{C}$ for $3 \mathrm{~h}$. This method has also been preferentially employed by others to assess the total hydrolysable sugars in organisms, particles and sediments collected from various aqueous environments (Cowie \& Hedges 1984, Tanoue \& Handa 1987, D'Souza et al. 2003).

Aldose concentrations increased over the period of immersion, suggesting their production by the fouling microorganisms (Fig. 3a). Nevertheless, the relative contribution of the individual aldoses to the total aldoses varied over the period of immersion (Fig. 3b). This was probably due to changes in the composition of the biofilm organisms, the growth phase, and/or the environmental condition, including the light and nutritional status of the community.

Glucose was generally the most abundant aldose (39\%), and its abundance decreased ( 39 to $\sim 24 \mathrm{wt} \%$ ) between Days 5 and 15 of the immersion period (Fig. 3b). This aldose is the major constituent of the 
diatom storage polysaccharide $\beta,-1,3$ glucan, which is easily degraded by the in situ aquatic organisms and/or metabolised during the sinking of diatom cells (Tanoue \& Handa 1987). As a result, the observed decrease in glucose may indicate preferential removal of glucose-rich reserve polymers by heterotrophic microorganisms and/or its uptake by the respiring diatoms (Tanoue \& Handa 1987). Further, grazing can also reduce the glucose content. For example, Cowie \& Hedges (1996) reported selective utilisation of glucoserich polymers by copepod zooplankton when they are fed with the diatom Thalassiosira weissflogii. Moreover, D'Souza \& Bhosle (2001) observed that the glucose content in natural populations of diatoms decreased with the increase in nitrate and phosphate concentrations. Therefore, it is possible that the decrease in the glucose content of the biofilm was related to the nutrient status of the biofilm organisms.

Arabinose and xylose were relatively more abundant $(\sim 19 \mathrm{wt} \%)$ in biofilm at Day 1 of the immersion period (Fig. 3b). These sugars do not contribute significantly to either the cell or cell wall material of diatoms, but are abundant in terrestrial plants as constituents of arabinoxylan, arabino glucuronoxylan, etc. (Cowie \& Hedges 1984, Ogier et al. 2001). Moreover, these aldoses were relatively enriched in mangrove leaves, especially Kandelia (Table 3). The relative abundance of these sugars, therefore, may suggest the presence of terrestrial material in the biofilm developed on the SS at Day 1 of the immersion period (Hedges et al. 1985, Ogier et al. 2001).

Decrease in glucose, arabinose and xylose was associated with a relative increase in fucose, rhamnose, galactose and ribose (Fig. 3b). In some of the diatoms, glucose-rich polymers are replaced by fucose-rich storage polysaccharides (Percival 1970). Moreover, fucose is one of the abundant aldoses among the cell wall polysaccharides of the diatoms Nitzschia sp. and Navicula sp. (Hecky et al. 1973). The abundance of both these diatoms in the biofilm on the SS panels increased over the period of immersion (D'Souza 2004). Therefore, the increase in fucose content in the biofilm over the period of immersion probably indicates the influence of these diatoms.

The abundance of rhamnose (5.8 to $19.9 \%$ ), galactose $(\sim 24$ to $41 \%$ ) and ribose ( 7.4 to $19.1 \%$ ) in the biofilm also increased over the period of immersion. These sugars are relatively abundant in microorganisms, especially bacteria. For example, Pseudomonas sp., Azotobacter sp. and Caulobacter sp. are enriched in rhamnose (24 to $44 \%$ ) (Hicks et al. 1994). Similarly, ribose (11 to $61 \%$ ) and galactose $(\sim 24$ to $41 \%)$ are enriched in some unidentified marine bacteria, including fouling bacteria (10 to 30\%) (Cowie \& Hedges 1984, D'Souza 2004). These bacteria were found in the biofilm developed on metal panels immersed in the surface waters of the study area (D'Souza \& Bhosle 2003a). Therefore, the observed increase in the contribution of rhamnose, fucose, ribose and galactose to the total aldoses over the period of immersion indicates the contribution from bacteria and diatoms.

In order to further define the major sources of biofilm OM, the aldose composition data of the biofilm and the source samples were further processed using PCA. Plots of the PCA loadings for Factor 1 vs. Factor 2 separated the variables into clusters (Fig. 4). The biofilm samples merged with mangroves and macroalgae, indicating the contribution of mangroves and macroalgae to the biofilm OM that developed on the SS plates at Day 1 of the immersion period (Fig. 4). Subsequently, at Day 3 of immersion, the biofilm samples were roughly distributed inside the square along with diatoms, bacteria and macroalgae, indicating that the aldoses were mostly derived from these sources. At Day 5, further change in the biofilm community structure was revealed by the close clustering of the biofilm samples with diatoms and bacteria. As the immersion period continued (10 and $15 \mathrm{~d}$ ), diatoms formed a close cluster with biofilm samples, thereby indicating the predominance of OM derived from microalgae.

\section{Nature of the biofilm organic matter}

The contribution of $\mathrm{TCHO}_{\mathrm{sp}}-\mathrm{C}$, protein-C and total aldoses-C to the total OC in a sample is a useful tool to evaluate the degradation state of the OM (Cowie et al. 1995, Skoog \& Benner 1997, D'Souza \& Bhosle 2003b). Carbohydrates and proteins account for 30 to $70 \%$ of the OM in all types of fresh marine and terrestrial sources; these values decrease during the degradation of OM (Hedges et al. 1994, Cowie et al. 1995, Pantoja \& Lee 1999). At Day 1 following immersion, the contribution of $\mathrm{TCHO}_{\mathrm{SP}}-\mathrm{C}$ plus protein-C and the total aldoses-C to the biofilm OC varied between $\sim 5.6$ and 8.9 and 0.37 and $2.2 \%$, respectively (Table 2 ). Compared to the live marine and terrestrial materials, these values were low, suggesting the presence of extensively degraded OM in the biofilm developed on SS at Day 1 following immersion. As the immersion period continued, the contribution of $\mathrm{TCHO}_{\mathrm{SP}}-\mathrm{C}$ plus proteinC ( 23 to $39 \%)$, and total aldoses-C ( 2 to $9 \%)$ to the total biofilm OC increased, implying a relative abundance of fresh biogenic OM in the biofilm (Table 2). Nevertheless, only $\sim 6$ to $39 \%$ of OC was accounted for by carbohydrates and proteins in the biofilm samples, which means that $\sim 61$ to $94 \%$ of the biofilm OC remained uncharacterised. Although lipids may account for a certain portion, much of the OM remained unidentified. However, this was not an 
unusual observation. For example, Wang et al. (2004) reported that 35 to $49 \%$ of the OC of estuarine samples remained uncharacterised. Similarly, in Delaware Bay, 61 to $79 \%$ of the OC remained uncharacterised (Harvey \& Manino 2001). This molecularly uncharacterised OM may indicate the presence of biologically and chemically modified OM and/or failure of the modern hydrolysis methods (Skoog \& Benner 1997, Ogawa et al. 2001). It will be interesting to determine the role of this OM in the development of biofilm.

Acknowledgements. The authors thank Dr. S. R. Shetye and Dr. E. Desa, the director and the ex-director, respectively, of the institute for facilities and encouragement. We also thank the Department of Ocean Development, Government of India, for financial help. F.D. thanks the Council of Scientific and Industrial Research, New Delhi, for the Senior Research Fellowship (SRF). This is NIO Contribution No. 4022.

\section{LITERATURE CITED}

Baier RE (1984) Initial events in microbial film formation. In: Costlow JD, Tipper RC (eds) Marine biodeterioration: an interdisciplinary study. US Naval Institute, Annapolis, MD, p 63-67

Bhosle NB, Wagh AB (1997) Amino acids in biofilm material on aluminum panels immersed in marine waters. Biofouling 11:149-166

Bhosle NB, Nandakumar K, Venkat K, Dhople VM, Sawant SS, Wagh AB (1989) Biological and biochemical characterization of microfouling on aluminium panels placed in the Arabian Sea. Proc Indian Natl Sci Acad 55:51-56

Bhosle NB, Evans LV, Edyean RGJ (1993) Carbohydrates production by Amphora coffeaeformis, a marine fouling diatom. Biofouling 7:81-91

Bhosle NB, Sawant SS, Garg A, Wagh AB (1995) Isolation and partial chemical analysis of exopolysaccharides from the marine fouling diatom Navicula subinflata. Bot Mar 38: 103-110

Bott TR (1993) Aspects of biofilm formation and destruction. Corros Rev 11:1-24

Buridge DJ, Skoog A, Gardner K (2000) Dissolved and particulate carbohydrates in contrasting marine sediments. Geochim Cosmochim Acta 64:1029-1041

Characklis WG, Cooksey KE (1983) Biofilm and microbial fouling. Adv Appl Microbiol 29:93-138

Characklis WG, Escher AR (1988) Microfouling in initial events. In: Thompson MF, Sarojini R, Nagabushanam R (eds) Marine biodeterioration: advanced techniques applicable to the Indian Ocean. Oxford and IBH Publ, New Delhi, p 249-260

Compere C, Bellon-Fontaine MN, Bertrand P, Costa D and 5 others (2001) Kinetics of conditioning layer formation on stainless steel immersed in seawater. Biofouling 17: 129-145

Corzo A, Morillo JA, Rodriguez S (2000) Production of transparent exopolymer particles (TEP) in cultures of Chaetoceros calcitrans under nitrogen limitation. Aquat Microb Ecol 23:63-72

Costerton JW, Cheng KJ, Geesey GG, Ladd TI, Nickel JC, Dasgupta M, Marie TJ (1987) Bacterial biofilms in nature and disease. Annu Rev Microbiol 41:435-465
Cowie GL, Hedges JI (1984) Carbohydrate sources in a coastal marine environment. Geochim Cosmochim Acta 48:2075-2087

Cowie GL, Hedges JI (1992) The role of anoxia in organic matter preservation in coastal sediments: relative stabilities of the major biochemicals under oxic and anoxic depositional conditions. Org Geochem 19:229-234

Cowie GL, Hedges JI (1996) Digestion and alteration of the biochemical constituents of a diatom (Thalassiosira weissflogii) ingested by an herbivorous zooplankton (Calanus pacificus). Limnol Oceanogr 41:581-594

Cowie GL, Hedges JI, Prahl FG, deLange GJ (1995) Elemental and biochemical changes across an oxidation front in a relict turbidite: an oxygen effect. Geochim Cosmochim Acta 59:33-46

Decho AW (1990) Microbial exopolymer secretions in open ocean environments: their role(s) in food webs and marine progresses. Oceanogr Mar Biol Annu Rev 28:73-153

Decho AW (2000) Microbial biofilms in intertidal systems: an overview. Cont Shelf Res 20:1257-1273

D'Souza F (2004) Study on bacterial exopolysaccharides and their role in adhesion and corrosion. PhD thesis, Goa University, Bambolim, Goa

D'Souza F, Bhosle NB (2001) Variation in the composition of carbohydrates in the Dona Paula Bay (west of India) during May/June 1998. Oceanol Acta 24:221-237

D'Souza F, Bhosle NB (2003a) Biofilm development on metal surfaces in tropical marine waters. In: Hiremath KG (eds) Recent advances in environmental sciences. Discovery Publishing House, New Delhi, p 441-458

D'Souza F, Bhosle NB (2003b) Analysis of microfouling products formed on metallic surfaces exposed in a marine environment. Biofouling 19:95-107

D'Souza F, Garg A, Bhosle NB (2003) Biogeochemical characteristics of sedimenting particles in Dona Paula Bay, India. Estuar Coast Shelf Sci 58:311-320

Dubois M, Gilles KA, Hamilton JK, Rebers PA, Smith F (1956) Calorimetric method for determination of sugars and related substances. Anal Chem 28:350-356

Handa N, Tominaga H (1969) A detailed analysis of carbohydrates in marine particulate matter. Mar Biol 2:228-235

Harvey HR, Manino A (2001) The chemical composition and cycling of particulate and macromolecular dissolved organic matter in temperate estuaries as revealed by molecular organic tracers. Org Geochem 32:527-542

Hecky RE, Mopper K, Kilham P, Degens ET (1973) The amino acid and sugar composition of diatom cell walls. Mar Biol 19:323-331

Hedges JI, Cowie GL, Ertel JR, Barbour RJ, Hatcher PG (1985) Degradation of carbohydrates and lignins in buried woods. Geochim Cosmochim Acta 49:701-711

Hedges JI, Cowie GL, Richey JE, Quay PP, Benner R, Strom N, Forsberg BR (1994) Origins and processing of organic matter in the Amazon River as indicated by carbohydrates and amino acids. Limnol Oceanogr 39:743-761

Hicks RA, Owen CJ, Aas P (1994) Deposition, resuspension, and decomposition of particulate organic matter in the sediments of Lake Itasca, Minnesota, USA. Hydrobiologia 287:79-91

Hitchcock GL (1978) Labelling pattern of carbon 14 in net plankton during a winter spring bloom. J Exp Mar Biol Ecol 31:141-153

Ittekkot V, Degens ET, Brockman U (1982) Monosaccharide composition of acid hydrolyzable carbohydrates in particulate matter during plankton bloom. Limnol Oceanogr 27: 770-776

Khandekar N, Johns RB (1990) Marine corrosion studies. II. A biomarker study tracing the early formation of biofilms on 
steel plates in a marine environment. Org Geochem 15: 531-538

Loeb GI, Neiholf RA (1977) Adsorption of an organic film at a platinum seawater interface. J Mar Res 35:283-291

Maki JS, Little BJ, Wagner P, Mitchell R (1990) Biofilm formation on metal surface in Antarctic waters. Biofouling 2: $27-38$

Maksymowska D, Richard P, Tankowska HP, Riera P (2000) Chemical and isotopic composition of the organic matter sources in the Gulf of Gdarisk (southern Baltic Sea). Estuar Coast Shelf Sci 51:585-598

Myklestad S (1977) Production of carbohydrates by marine planktonic diatoms. II. Influence of N/P ratio in the growth medium on the assimilation ratio, growth rate, and production of cellular and extracellular carbohydrates by Chaetoceros affinis and Skeletonema costatum. J Exp Mar Biol Ecol 29:161-179

Ogawa H, Amagai I, Koike I, Kaiser K, Benner R (2001) Production of refractory dissolved organic matter by bacteria. Science 292:917-920

Ogier S, Disnar JR, Alberic P, Bourdier G (2001) Neutral carbohydrate geochemistry of particulate material (trap and core sediments) in an eutrophic lake (Aydat, France). Org Geochem 32:151-162

Oleson M, Lundsgaard C (1995) Seasonal sedimentation of autochthonous material from the euphotic zone of a coastal system. Estuar Coast Shelf Sci 41:475-490

Otero A, Dominguez A, Lamela T, Garcia D, Fabregas J (1998) Steady-states of semicontinuous cultures of a marine diatom: effect of saturating nutrient concentrations. J Exp Mar Biol Ecol 227:23-34

Pantoja S, Lee C (1999) Molecular weight distribution of proteinaceous material in Long Island Sound sediments. Limnol Oceanogr 44:1323-1330

Parson TR, Matai Y, Lalli CM (1984) A manual of chemical and biological methods of seawater analysis. Pergamon Press, New York

Percival E (1970) Algal carbohydrates. In: Pigman W, Horton D (eds) The carbohydrates: chemistry and biochemistry, Vol IIB, 2nd edn. Academic Press, New York, p 537-568

Rao TS (2003) Temporal variations in an estuarine biofilm: with emphasis on nitrate reduction. Estuar Coast Shelf Sci 58:67-75

Read RR, Costerton JW (1987) Purification and characterization of adhesive exopolysaccharides from Pseudomonas putida and Pseudomonas fluorescens. Can J Microbiol 33: 1080-1090

Rice A, Hamilton M, Camper A (2000) Apparent surface associated lag time in growth of primary biofilm cells. Microbial Ecol 40:8-15

Sharma OM, Bhosle NB, Wagh AB (1990) Methods for the removal and estimation of microfouling biomass. Indian $\mathrm{J}$ Mar Sci 19:174-176

Skoog A, Benner R (1997) Aldoses in various size fractions of

Editorial responsibility: Staffan Kjelleberg,

Sydney, Australia marine organic matter: implications for carbon recycling. Limnol Oceanogr 42:1803-1813

Smart MM, Rada RG, Donermeyer GN (1983) Determination of total nitrogen in sediments and plants using persulphate digestion. Water Res 17:1207-1211

Smith PK, Krohn RI, Hermanson GT, Mallia AK and 6 others (1985) Measurement of protein using bicinchoninic acid. Anal Biochem 150:76-85

Sokal RR, Rohlf JF (1981) Biometry, 2nd edn. Freeman, San Francisco, CA

Sonak S, Bhosle NB (1995) Observations on biofilm bacteria isolated from aluminium panels immersed in estuarine waters. Biofouling 8:234-254

Tanoue E, Handa N (1987) Monosaccharide composition of marine particles and sediments from Bering Sea and northern North Pacific. Oceanol Acta 10:91-99

Taylor GT, Zheng D, Lee M, Troy PJ, Gyananath G, Sharma SK (1997) Influence of surface properties on accumulation of conditioning films and marine bacteria on substrata exposed to oligotrophic waters. Biofouling 11:31-57

Vandevivere P, Kirchman DL (1993) Attachment stimulates exopolysaccharide synthesis by a bacterium. Appl Environ Microbiol 59:3280-3286

Verity PG (2002) A decade of change in the Skidaway river estuary. II. Particulate organic carbon, nitrogen, and chlorophyll a. Estuaries 25:961-975

Verity PG, Robertson CY, Tronzo CR, Andrews MG, Nelson JR, Sieracki ME (1992) Relationships between cell volume and the carbon and nitrogen content of marine photosynthetic nanoplankton. Limnol Oceanogr 37:1434-1446

Wang XC, Altabet MA, Callahan J, Chen RF (2004) Stable carbon and nitrogen isotopic compositions of high molecular weight dissolved organic matter from US estuaries. Geochim Cosmochim Acta 68:2681-2691

Welch SA, Barker WW, Banfield JF (1999) Microbial extracellular polysaccharides and plagioclase dissolution. Geochim Cosmochim Acta 63:1405-1419

White DC, Benson PH (1984) Determination of biomass, physiological status, community structures and extracellular plaque of microfouling film. In: Costlow JD, Tipper RC (eds) Marine biodeterioration: an interdisciplinary study. US Naval Institute, Annapolis, MD, p 68-74

Wieczorek SK, Clare AS, Todd CD (1995) Inhibitory and faciltatory effects of microbial films on settlement of Balanus ampheterite larvae. Mar Ecol Prog Ser 199:221-228

Wingender J, Neu TR, Flemming HC (1999) What are bacterial extracellular polymeric substances? In: Wingender J, Neu TR, Flemming HC (eds) Microbial extracelluar polymeric substances: characterization, structure and function. Springer-Verlag, Berlin, p 1-20

Wolfaardt GM, Lawrence JR, Darren RK (1999) Function of EPS. In: Wingender J, Neu TR, Flemming HC (eds) Microbial extracelluar polymeric substances: characterization, structure and function. Springer-Verlag, Berlin, p 171-200

Submitted: February 10, 2005; Accepted: August 17, 2005

Proofs received from author(s): November 11, 2005 